Ivana Kostadinović ${ }^{1}$

University of Niš, Faculty of economics

Sunčica Stanković ${ }^{2}$

Center for strategic researching and national security - CESNA B, Belgrade
ORIGINAL SCIENTIFIC ARTICLE doi:10.5937/ekonomika2001025K

Received: November, 22. 2019.

Accepted: December, 21. 2019.

\title{
THE ANALYSIS OF THE REGIONAL DISPROPORTIONS IN THE LABOR MARKET IN THE REPUBLIC OF SERBIA
}

\begin{abstract}
The subject of research are regional disproportions in the labor market in Serbia. The purpose of this study is: 1) to identify Serbian low-paid industrial sectors, as well as 2) to examine regional differences in wages of workers. To achieve these goals, we were used official data of the Statistical Office of the Republic of Serbia on employment and wage distribution by sector of activity. Based on methodology suggested by Nestić et al. (2018), we were identified 7 low-paid industrial sectors in Serbia. Paired-Sample T Test results indicate significant disproportion in wages of workers according to regions. The results obtained indicate the necessity of giving more space to issues of regional disproportions by economic policy-makers.
\end{abstract}

Key words: low - paid industrial sectors, low - wages, minimum wages, regional differences in wages

JEL classification: J21, J31

\section{АНАЛИЗА РЕГИОНАЛНИХ ДИСПРОПОРЦИЈА НА ТРЖИШТУ РАДА У РЕПУБЛИЦИ СРБИЈИ}

\section{Апстракт}

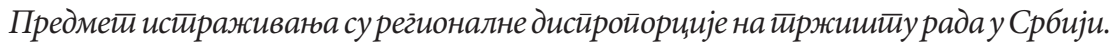
Циљ рада је: 1) иденйификаиија слабо йлаћених индустиријских секйора у Србији, као и 2) исиичиииване регіионалних разлика узарадама радника. Радийосиизаньа ових изитева коришћени су званични йодаци Сйайистичког̈ завода Рейублике Србије о зайосленосиии и дисирибуиији зарада ирема секитору делаитносиии. На основу метиодологије коју су иредложили Нестић и сарадници (2018), иденииификовали смо 7 слабо йлаћених индустиријских секииора у Србији. Резулитайи уйареног $t$ - ииесииа указују на значајну дисироиорициу у зарадама радника иррема регионима. Добијени

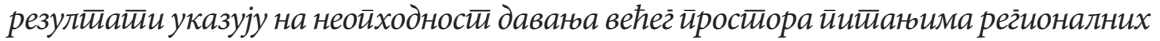
дисиройориија од сииране креайора економске йолийике.

Клучне речи: ниско йлаћени индусйријски секитори, ниске зараде, минималне зараде, регіионалне разлике у зарадама.

\footnotetext{
${ }^{1}$ ivana.kostadinovic@eknfak.ni.ac.rs, ORCID ID https://orcid.org/ 0000-0002-7676-3472

${ }^{2}$ suncicas372@gmail.com, ORCID ID https://orcid.org// 0000-0001-8824-1973
} 


\section{Introduction}

Regional inequality is a phenomenon that characterizes most countries. Serbia is no exception in this respect (Molnar, 2013, p. 179). Differences in development between regions in Serbia, but also differences in development between districts within the region, are very pronounced. Gross domestic product per capita, expressed in PPS (Purchasing Power Standard), in 2017 was only $38.7 \%$ of the EU-28 average. At the same time, the most developed region in Serbia (Belgrade) is at a level of development of $65.0 \%$, while the least developed region (South and Eastern Serbia) is at a level of development of only $24.6 \%$ of the EU-28 average (Statistical Office of the Republic of Serbia, 2019, p. 13).

Regional disproportions in general, and inter-regional differences in the labor market in particular, are of increasing importance in Serbia. Growing regional disproportions brings many economic, social and political risks, indicating need for economic policy makers to address this problem in a timely manner. The problem of unemployment in Serbia should be viewed from a regional perspective for three reasons. First, the scope of labor market variation across regions in Serbia is very large. Second, macroeconomic studies do not explain why there are differences in regional labor markets. Also, labor market institutions (for example: employment and dismissal rules, negotiation of wages, social security, retirement rules and the tax system) do not differ between regions. Third, excessive and persistent differences in the regional characteristics of the labor market, especially wages and unemployment rates, are a sign of inefficient allocation of labor as a basic economic resource (Arandarenko, 2006, pp. 5-6).

The level of wages and their dynamics are important for the economic development and social stability of both a particular country and its regions. Economically speaking, the imbalance in wage growth relative to production and productivity trends can have negative consequences. Low-wages can be a constraint on a country's economic growth, while high wages can weaken a country's competitive position. From a social perspective, wages are the most important source of income for the largest number of individuals in each country. Consequently, the living standard of the population largely depends on the level and dynamics of wages, which all have an impact on social cohesion in the country (Anić, \&. Vuksanović, 2019, p. 64). Based on these facts, the purpose of this research is twofold. First, we try to identify low-paid industrial sectors in Serbia, and second, we try to examine regional differences in workers' wages. This analysis is based on method suggested by Nestić et al. (2018) and by available statistical data. The paper is organized into seven parts. Following the introductory presentation in the first part, the second part presents a brief overview of the literature relating to minimum wages and regional disproportions. The third part defines the research methodology. The fourth part identifies 7 low-paid industrial sectors most affected by minimum wage policy. In the fifth part, regional differences in the workers' wages in Serbia are examined. The sixth part presents the indicators of the labor market in Serbia. The seventh part concludes the paper.

\section{Literature review}

In recent years, in some countries, regardless of their level of development, low-wage employment increases, while in others reduces (McKnight et al., 2016, p. 3). McKnight et al. (2016) find a positive relation between wage inequality and frequency of low-wage countries 
with greater inequality tendentious have greater participation of employees in low-paid work than in countries with greater equality. The incidence of low-wages in some industries is more frequently than others, for two reasons: 1) low-paid workers do not work in some industries that are open to global competition and 2) a significant proportion of low-paid workers working in the public sector, where the government has more direct control over the level of wages (The Poverty Site, 2010). Earnings inequality is large and growing in many countries.

Different countries use different instruments for market regulation in an attempt to alleviate inequalities in the labor market, including minimum wage (Boeri et al., 2019). Minimum wage is the minimum amount paid to the worker per working hour. According to the methodology of Eurostat, it is related to a gross income - or net income with taxes and contributions (Eurostat, 2019). Minimum wage is a guaranteed amount that the employee receives, as the basis of work, and in other cases, such as, for example, sick leave. Empirical results of individual studies suggest that generally minimum wages reduce inequality in earnings (e.g. Rubery, 2003; Manning, 2003), while results of other studies suggest that effects of minimum wage are higher in sectors of low-wage (e.g. Di Nardo et al.1996; Lee, 1999; Butcher et al., 2012). Dickens et al. (1994, p. 28) find that minimum wages "have compressed the distribution of earnings and probably raised employment". The growth of minimum wage may have contradictory effects on income inequality. On the one hand, "people at the bottom of the distribution" achieve higher earnings; on the other hand, it can lead to people "being excluded from employment" (Garnero et al., 2015, p. 116-117). Minimum wage policy aims are to increase the earnings of low-paid workers and guarantee living standard to their families, reduce inequality (Xing, \& Xu, 2016, p. 2), and protection of workers in low-wage sectors through "a combination of collective agreements and the statutory minimum wages" (International Labour Organization, p. 15). Some countries apply minimum wage uniform policy across the country, and others for different regions, industries, and for employment according to the age, gender and education (Rani et al., 2013; Xing, \& Xu, 2016). As one of the proposal to reduce inequality, Atkinson (2015) said that a national pay policy, in addition to a minimum wage should be introduced rules for determining wages above the minimum through arrangements within the Social-Economic Council.

According to Anić and Vuksanović (2019, p. 73), Serbia has among the lowest minimum wage per hour, expressed both in current euros and euros in the same purchasing power compared to European countries. However, the analysis of minimum and median and minimum and average wages ratios gives a different picture. The ratio of minimum and average gross wages in Serbia compared to other countries is relatively high and amounts to almost 50\%. Minimum and median gross wages ratio is $63 \%$ in the first half of 2019 . Compared to OECD countries, this ratio is among the highest.

Researchers of regional perspectives, in recent decades, „have led to academic and policy debates on the state of regional economies" globally, primarily focused "on ideas of regional aspects of economic and institutional forms, inequality and the spatiality of power" (Donald \& Gray, 2018, p. 297). Regardless of the fact that there is no generally accepted and consistent definition of regional disproportions (disparities), it can be said that regional disproportions are differences in socio-economic development between regions, which arise as a result of some inequalities (Tvrdon \& Skokan, 2011). In relation to regional differences, regional disproportions are a broader term because they cover not only the existence of unbalances between individual regions, "but also the convergence and polarization of regions" (Ibid, p.2). Although there is no universal synthetic indicator for measuring regional 
disproportions within the EU member states and candidate countries, on the basis of a comparative analysis of individual socio-economic indicators can be considered that Serbia marking perhaps the greatest regional disproportions, both among Balkan neighbors and all over Europe (Vukmirović, 2013, p. 39, Manić et al., 2017). The spatial aspect of development is almost completely ignored in our public policies (Molnar \& Manić, 2018, p. 8). In terms of institutions, regional development is now "down “ to the level of responsibility of the minister without portfolio (Ibid). The level of economic development, regional characteristics and opportunities in the labor market lead to significant differences in wages by Serbian regions. In april 2019, the average level of wages in the region of Šumadija and Western Serbia amounted to $69.13 \%$ of the average wage level of employees in the Belgrade region.

In the extensive literature on disproportions in regional labor markets, two main strategic approaches have been applied mainly to explain differences in unemployment rates and other aspects of the labor market: theoretical (based on abstract economic models) or empirically (based on indications taken from data) (Arandarenko, 2006, p. 10).

\section{Research Methodology}

"When defining methodology of research, it is important to determine indicators which will provide all relevant aspects pertaining to the problem" (Stanković, 2016, p. 592) of regional disproportion in the labour market. The first group of indicators relate to employment in the labour market. The second group of indicators relate to workers' wages in the labour market.

The subject of research are the regonal disproportions in the labor market in Serbia. The purpose of this research is to: 1) identify Serbian low-paid industrial sectors, as well as 2) examine regional differences in wages of workers. In order to achieve these goals, official data of the Statistical Office of the Republic of Serbia on employment and wage distribution by sector of activity, were used.

To realize the first purpose of this research we followed the methodology which was first applied by Nestić et al. (2018) to identify low - wage sectors and regions in Croatia, and then, Majchrowski \& Strawiński (2019) to identify low - wage regions in Poland. Nestić et al. (2018, p. 1985) defined criteria for the selection of low-paid industrial sectors: minimum wage in that sector receive more than $8 \%$ workers; the total number of workers for minimum wage in this sector need to be at least $1 \%$; the proportion of minimum wage to the sector median wage must be higher than $60 \%$, and to the sector average wage must be higher than $50 \%$. Due to the unavailability of data, the third criterion which relates to median earnings was not applied.

Starting from second research purpose of research, hypothesis was tested:

$\mathrm{H}_{1}$ : There is a statistically significant difference in wages of workers in Belgrade region and wages of workers in region of Vojvodina, Šumadija and Western Serbia, and Southern and Easthern Serbia.

In accordance with defined hypothesis $\mathrm{H}_{1}$ Paired-Sample $\mathrm{T}$ Test was used. Statistical package SPSS IBM Statistics Version 17 was used for data processing. 


\section{Labor market in Serbia}

In the population structure by work status (Figure 1), in the observed period (I quarter, 2017 - I quarter, 2019), regions have different distribution. The highest employment rates of the working-age population (15 and over) were recorded in the Belgrade region, while the lowest in the region of South and East Serbia. Otherwise, employment rates in the Belgrade region have increased by about $6 \%$ over the whole observed period compared to the region of South and Eastern Serbia. Unemployment rates are higher in the Southern and Eastern Serbia and the Sumadija and Western Serbia regions, compared to the unemployment rates in the Belgrade and Šmadija and Western Serbia regions. The inactivity rates of the working-age population are lower in the Belgrade and Šumadija and Western Serbia regions, compared to the inactivity rates in the Vojvodina and Southern and Eastern Serbia regions.

Figure 1. Main labor market indicators by regions in Serbia, I quarter: 2017, 2018, 2019 (in \%)

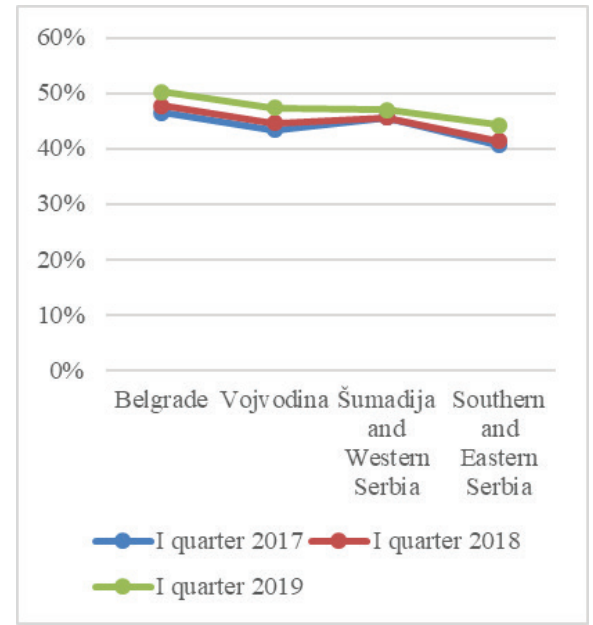

a) Employment rate of population

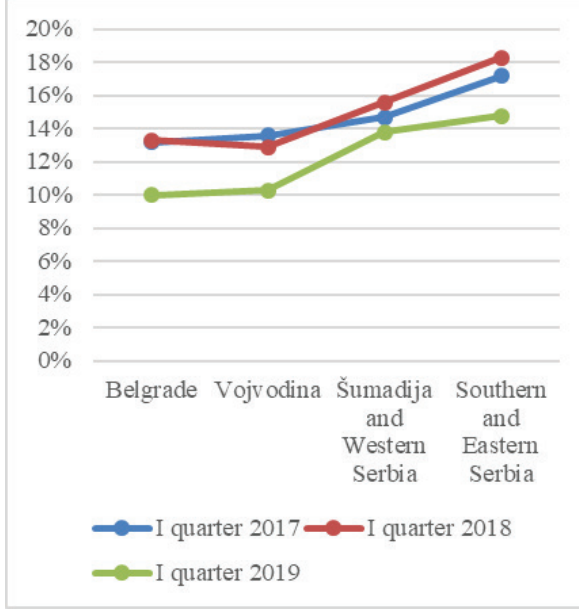

b) Unemployment rate of population

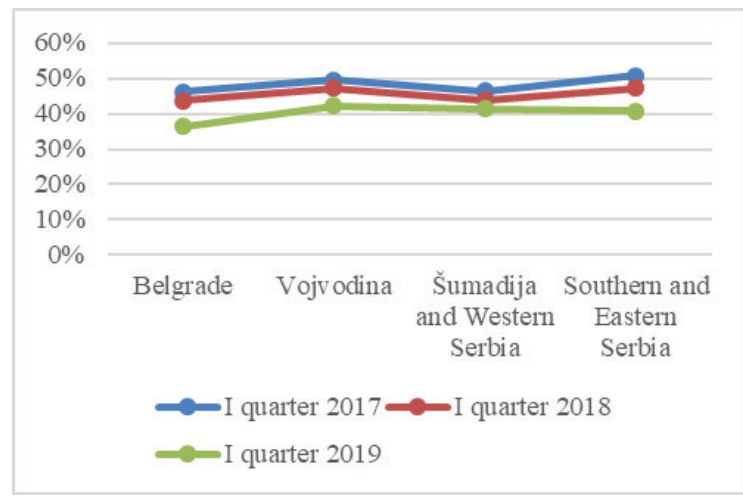

c) Inactivity of population

Source: Statistical Office of the Republic of Serbia, Labour Force Survey in Serbia (communications), I quarter: 2017, 2018, 2019 
As we can see, according to the Labor Force Survey, significant changes have been made in the labor market of Serbia. In the observed period there were an increase in employment and a decrease in unemployment, as well as a decrease in the inactivity rate in all regions. However, regional disparities remain high.

\section{Identifying low-paid industrial sectors and wage dynamics}

To identify low-paid industrial sectors the methodology applied by Nestić et al. (2018) was followed. In accordance with the proposed methodology, the first step was to examine the share of employees with low wages by sectors, and industrial sectors in which less than $8 \%$ of workers achieve low wages were eliminated. In the next step, it was checked whether employees in these sectors make up at least $1 \%$ of the total number of employees with low wages, and based on that sectors in which employees are at low wage level, but their number is less than proposed level were eliminated. Then, it was checked whether minimum wage of the sector accounts for more than $50 \%$ of average earnings in the sector, so as to excluded sectors where in some areas of employment, the employees have low wages, but at the level of the whole sector average wages are high.

Based on the applied methodology 7 low-paid industrial sectors in the Republic of Serbia, or sectors in which wages of employees are a little bit higher than minimum wage were identified and there are: manufacture of clothing, retail trade, expect of motor vehicles the activity of preparing and serving food and drinks, security and investigation activities, services to buildings (cleaning etc.), repair of computers and items for personal use, and other personal service activities (Table 1). The share of low-paid workers across all industrial sectors is $20.94 \%$. In the sector manufacture of clothing the earning realized by employees makes $71.14 \%$ of the average wage sector; retail trade, expect of motor vehicles $82.32 \%$; in the sector the activity of preparing and serving food and drinks $91.54 \%$; security and investigation activities $78.75 \%$; services to buildings (cleaning etc.) 75.24\%; repair of computers and items for personal use $78.19 \%$; and in the sector other personal service activities $77.98 \%$ of the average wage.

Table 1. Low-paid sectors in Serbia (I quarter, 2019)

\begin{tabular}{|l|c|c|c|}
\hline \multicolumn{1}{|c|}{ Sector } & $\begin{array}{c}\text { Share of low- } \\
\text { wage workers in } \\
\text { the sector }\end{array}$ & $\begin{array}{c}\text { Share of low- } \\
\text { wage workers } \\
\text { in total nomber } \\
\text { of low-wage } \\
\text { workers }\end{array}$ & $\begin{array}{c}\text { Low to } \\
\text { average wage } \\
\text { in net terms } \\
\text { (in april, } \\
2019)\end{array}$ \\
\hline Manufacture of clothing & $8.19 \%$ & $1.79 \%$ & $71.14 \%$ \\
\hline Retail trade, expect of motor vehicles & $59.09 \%$ & $44.76 \%$ & $82.32 \%$ \\
\hline The activity of preparing and serving food and drinks & $80.20 \%$ & $3.14 \%$ & $91.54 \%$ \\
\hline Security and investigation activities & $27.95 \%$ & $6.54 \%$ & $78.75 \%$ \\
\hline Services to buildings (cleaning etc.) & $16.93 \%$ & $3.96 \%$ & $75.24 \%$ \\
\hline Repair of computers and items for personal use & $19.01 \%$ & $1.76 \%$ & $78.19 \%$ \\
\hline Other personal service activities & $51.18 \%$ & $1.03 \%$ & $77.98 \%$ \\
\hline Serbia - all sectors & $20.94 \%$ & $100 \%$ & $64.17 \%$ \\
\hline
\end{tabular}

Source: Authors' calculation based on data of the Statistical Office of the Republic of Serbia 
Minimum wage is legally prescribed amount of money that can be paid to the employee for his work, after work during a certain period. Minimum net salary in Serbia in April 2019 amounted to 155.30 RSD per hour of work, that is 27.332,80 RSD per month. In April 2019, minimum monthly net wage was recorded in the sector the activity of preparing and serving food and drinks, and amounted to $31.242 \mathrm{RSD}$, which is about $14.3 \%$ higher than minimum net wage and makes a little bit more than $91 \%$ of the average wage sector. Remaining sectors where wages of employees are about minimum wages are: other personal service activities (32.445 RSD), repair of computers and items for personal use (32.531 RSD), manufacture of clothing (35.009 RSD), services to buildings (cleaning etc.) (37.212 RSD), retail trade, except of motor vehicles (38.060 RSD), and security and investigation activities (38.947 RSD). This means that these sectors are most affected by policy of minimum wages, particularly sectors: the activity of preparing and serving food and drinks, in which the share of employed with low income in the sector for the whole reference period is greater than $80 \%$, and sectors retail trade, expect of motor vehicles, and other personal service activities in which the share of employed with low income is greater than $50 \%$. Low-paid sectors and estimation of average net wage are presented in Table 2.

Based on the data presented in Table 2 may also be noted that earnings in identified low-paid industrial sectors during 2017, 2018 and 2019 were a little bit above the level of minimum wage and below the average wage at the state level. During the period, there was an increase for workers' wages in low-paid industrial sectors on average of about $8 \%$, while minimum wage increased by about 31\%. In the period 2017 - 2018 there was a reduction in average wages by $1.04 \%$, while in the period from 2018 - 2019 the average wage increased by $11.25 \%$.

Table 2. Low-paid sectors and estimation of average net wage

\begin{tabular}{|c|c|c|c|c|c|}
\hline \multirow{3}{*}{ Sector } & \multicolumn{3}{|c|}{ Average net wage (in RSD) } & \multicolumn{2}{|c|}{ Change in average } \\
\hline & \multicolumn{3}{|c|}{ April } & \multirow{2}{*}{$\begin{array}{c}2017 \\
- \\
2018\end{array}$} & \multirow{2}{*}{$\begin{array}{c}2018 \\
- \\
2019\end{array}$} \\
\hline & 2017 & 2018 & 2019 & & \\
\hline Manufacture of clothing & 29.113 & 31.592 & 35.009 & 8.52 & 10.82 \\
\hline Retail trade, except of motor vehicles & 31.031 & 35.366 & 38.060 & 13.97 & 7.62 \\
\hline $\begin{array}{l}\text { The activity of preparing and serving food } \\
\text { and drinks }\end{array}$ & 26.417 & 28.953 & 31.242 & 9.60 & 7.91 \\
\hline Security and investigation activities & 31.062 & 35.167 & 38.947 & 13.22 & 10.75 \\
\hline Services to buildings (cleaning etc.) & 36.679 & 34.567 & 37.212 & -11.13 & 10.77 \\
\hline $\begin{array}{l}\text { Repair of computers and items for personal } \\
\text { use }\end{array}$ & 25.917 & 30.301 & 32.531 & 16.92 & 7.36 \\
\hline Other personal service activities & 28.125 & 30.075 & 32.445 & 6.93 & 7.88 \\
\hline Serbia - all sectors & 49.635 & 49.117 & 54.645 & -1.04 & 11.25 \\
\hline
\end{tabular}

Source: Authors' calculation based on data of the Statistical Office of the Republic of Serbia

\section{Examining regional differences in workers' wages}

Table 3 shows that there are significant differences in outcomes that realized workers in Serbian regions, and wages of workers in Belgrade region are higher than realized wages by employees in other regions. On regional basis, employees in the region of Belgrade and 
the region of Vojvodina, achieve higher wages in relation to wages in the region of Šumadija and Western Serbia and the South and East Serbia. Employees in the region of Šumadija and Western Serbia achieved the smallest wage.

Table 3: Average gross wage by regions in april, 2017, 2018 and 2019 (in RSD)

\begin{tabular}{|c|c|c|c|c|}
\hline \multirow{2}{*}{ Year } & \multicolumn{4}{|c|}{ Region } \\
\cline { 2 - 5 } & Vojvodina & Belgrade & $\begin{array}{c}\text { Šumadija and } \\
\text { Western Serbia }\end{array}$ & $\begin{array}{c}\text { Southern and } \\
\text { Eastern Serbia }\end{array}$ \\
\hline 2017 & 67.344 & 84.840 & 56.346 & 59.001 \\
\hline 2018 & 64.408 & 82.755 & 58.977 & 60.325 \\
\hline 2019 & 71.167 & 93.389 & 64.556 & 66.541 \\
\hline
\end{tabular}

Source: Authors' calculation based on data of the Statistical Office of the Republic of Serbia

Hypothesis $\mathrm{H}_{1}$ is tested by applying Paired-Sample $\mathrm{T}$ Test. The result (Table 4) indicates that the difference in workers' wages in Belgrade region and region of Vojvodina is statistically significant. Realized value of the test statistic is 13.308, while the realised level of significance 0.006. The difference in workers' wages in Belgrade region and region of Šumadija and Western Serbia is statistically significant. Realized value of the test statistic is 16.571 , and the realized level of significance is 0.004. The difference in wages of workers in Belgrade region and region of Southern and Eastern Serbia is statistically significant. Realized value of the test statistic is 18.733 , and the realized level of significance is 0.003 . These results decidedly indicate significant disproportion in workers' wages in favour of workers in Belgrade region.

Table 4. Paired-Sample T Test results

\begin{tabular}{|c|c|c|c|c|c|c|}
\hline \multirow[b]{2}{*}{ Category } & \multicolumn{3}{|c|}{ Paired Differences } & \multirow[b]{2}{*}{$\mathrm{t}$} & \multirow[b]{2}{*}{ df } & \multirow[b]{2}{*}{ Sig. (2-tailed) } \\
\hline & Mean & Std. Deviation & $\begin{array}{l}\text { Std. Error } \\
\text { Mean }\end{array}$ & & & \\
\hline Belgrade - Vojvodina & 19355 & 2519.091 & 1454.398 & 13.308 & 2 & 0.006 \\
\hline $\begin{array}{l}\text { Belgrade - Šumadija and } \\
\text { Western Serbia }\end{array}$ & 27035 & 2825.733 & 1631.438 & 16.571 & 2 & 0.004 \\
\hline $\begin{array}{l}\text { Belgrade - Southern and } \\
\text { Eastern Serbia }\end{array}$ & 25039 & 2315.098 & 1336.623 & 18.733 & 2 & 0.003 \\
\hline
\end{tabular}

Source: Authors' calculation in SPSS

Thus, it can be concluded that the hypothesis $\mathrm{H}_{1}$ : there is a statistically significant difference between wages of workers in Belgrade region and wages of workers in region of Vojvodina, Šumadija and Western Serbia, and Southern and Easthern Serbia, is confirmed.

\section{Conclusion}

The existing regionalization of Serbia has so far failed to deliver the expected results, both in reducing regional disproportion in the labor market and in intensifying the development of less developed parts of the country. Therefore, the issue of appropriate regionalization in Serbia remains open and seems crucial to its future economic and social development (Molnar \& Manić, 2018). 
The unemployment problem in regions of Serbia is inherited from the pre-transition period and deepened by the transition process and global recession waves. During the observed period (I quarter: 2017 - 2019), unemployment decreased in all regions, but remained high. At the heart of economic policy and social protection should be job creation and all activities that will lead to employment.

Starting from the fact that the level of wages and their dynamics are important for the economic development and social stability of a country, and its regions, the aim of this research was to: 1) identify Serbian low-paid industrial sectors, as well as 2) examine regional differences in wages of workers. Based on the methodology applied over the official data on employment and earnings by the sector of activity of the Statistical Office of the Republic of Serbia, 7 low-paid industrial sectors in the Republic of Serbia were identified, namely: manufacture of clothing, retail trade, except of motor vehicles, the activity of preparing and serving food and drinks, security and investigation activities, services to buildings (cleaning etc.), repair of computers and items for personal use, and other personal service activities. This means that these sectors are most affected by policy of minimum wages, particularly sectors of the activity of preparing and serving food and drinks, where the share of employees with low wages in the sector for the whole observed period was greater than $80 \%$ and sectors retail trade, expect of motor vehicles, and other personal service activities in which the share of low income was greater than $50 \%$.

On the regional level, employees in region of Vojvodina and Belgrade achieve higher wages in relation to wages in region of Šumadija and Western Serbia and region of Southern and Eastern Serbia. The smallest wages earned by employees in region of Šumadija and Western Serbia, and the largest in Belgrade region. Namely, results of Paired-Sample T Test point to a significant disproportion of wages in Belgrade region and employees in other regions of the Republic of Serbia, based on which the hypothesis of the existence of significant statistical differences between workers' wages in Belgrade and workers' wages in region of Vojvodina, Šumadija and Western Serbia and Southern and Eastern Serbia was confirmed.

The growing regional inequality brings many economic, social and political risks (Arandarenko, 2006). The necessity of giving more space address to issues of regional disproportions by economic policy makers is one of the key implications of this research. It is necessary to define a new policy of balanced regional development that would reduce the regional disproportions, while enhancing their individual development and recognizable characteristics.

Identification of low-paid industrial sectors and regional differences in workers' wages can ease the decision making process to increase minimum wage, by continuous monitoring of these sectors and regions, both in earnings and in employment. In regard to this, giving special attention to representatives of social partners, from industrial sectors which are recognized in this paper as low-paid, in minimum wage negotiations is, also, a practical implication of this research.

Disadvantages of this research mainly reflected in the limitation of data only on average wages by industrial sectors, and by regions, while data of median wages (received by the largest number of employees in Serbia, and statistically, this is the value of which there is an equal number of smaller and larger amounts of paid wages) are not available. 


\section{References}

Anić, A., \& Vuksanović, N. (2019). Nivo, dinamika i nejednakost zarada u Srbiji. Kvartalni monitor br. 57, FREN, 64-74

Arandarenko, M. (ed.). (2006). Mapa tržišta rada Srbije. Centar za visoke ekonomske studije, Beograd

Atkinson, B. A. (2015). Inequality: what can be done? Harvard University Press. From: https://www.tony-atkinson.com/the-15-proposals-from-tony-atkinsons-inequalitywhat-can-be-done/

Boeri, T., Ichino, A., Moretti, E., \& Posch, J. (2019). Wage Equalization and Regional Misallocation: Evidence from Italian and German Provinces. NBER Working Paper No. 25612, Issued in February 2019. DOI: 10.3386/w25612

Butcher, T., Dickens, R., \& Manning, A. (2012). Minimum wages and wage inequality: some theory and an application to the UK. CEP Discussion Paper 1177, London. From https://core.ac.uk/download/pdf/9694943.pdf

Dakić, S., \& Savić, M. (2016). Analiza rodne ravnopravnosti u sferi rada na teritoriji Srbije. Anali Ekonomskog fakulteta u Subotici, (36), 161-175.

Di Nardo, J., Fortin, N. \& Lemieux, T. (1996). Labor market institutions and the distribution of wages, 1973 - 1992: a semiparametric approach. Econometrica, 64 (5),1001 - 1044. DOI: $10.2307 / 2171954$

Dickens, R., Machin, S., \& Manning, A. (1994). The effects of minimum wages on employment: Theory and evidence from the UK. NBER Working Paper No. 4742. DOI: $10.3386 / \mathrm{w} 4742$

Donald, B., \& Gray, M. (2018). The double crisis: in what sense a regional problem?. Regional Studies, 53(2), 297 - 308. DOI: 10.1080/00343404.2018.1490014

Eurostat. (2019). Minimum wage statistics / Statistics Explained. From https://ec.europa. eu/eurostat/statistics-explained/pdfscache/1568.pdf

Garnero, A., Kampelmann, S., \& Rycx, F. (2015). Minimum wage systems and earnings inequalities: Does institutional diversity matter?. European Journal of Industrial Relations 21(2), 115 - 130. DOI: 10.11770959680114527034

International Labour Organization. (2016). Minimum wage policy Guide. From https:// www.ilo.org/wcmsp5/groups/public/---ed_protect/---protrav/---travail/documents/ publication/wcms_508566.pdf

Lee, D. (1999). Wage inequality in the United States during the 1980s: rising dispersion or falling minimum wage?. Quarterly Journal of Economics, 114(3), 977-1023. DOI: $10.1162 / 003355399556197$

Majchrowska, A., \& Strawiñski, P. (2019). Minimum wage workers in the private sector in Poland: regional perspective. Lodz Economics Working Papers 2/2019, University of Lodz, Faculty of Economics and Sociology

Manić, E., Mitrović, Đ., \& Popović, S. (2017). Regional Disparity Analysis of Business Conditions: The Case of Serbia, Journal of Business Economics and Management, 65(3/4), 275-293. DOI:10.5937/EKOPRE1704275M 
Manning, A. (2003). The real thin theory: monopsony in modern labour markets. Labour Economics 10(2): 105-131. DOI:10.1016/S0927-5371(03)00018-6

Molnar, D. (2013). Dinamika i struktura regionalnih dispariteta u Srbiji tokom perioda 2001-2010. godine. Ekonomski vidici, XVIII (2-3), 175-187

Molnar, D. \& Minić, E. (2018). Nova subregionalizacija za novu ekonomsku politiku Srbije. Anali Ekonomskog fakulteta u Subotici, 54(40), 003-019. DOI:10.5937/ AnEkSub1840003M

McKnight, A., Stewart, Himmelweit, S., M., \& Palillo, M. (2016). Low pay and in-work poverty: preventative approaches. Eurepean Commission

Nestić, D., Babić, Z., \& Blažević, Burić, S. (2018). Minimum wage in Croatia: sectoral and regional perspectives, Economic Research-Ekonomska Istraživanja, 31(1), 19812002. DOI: 10.1080/1331677X.2018.1473787

Rani, U., Belser, P., Oelz, M. \& Ranjbar, S. (2013). Minimum wage coverage and complicnce in developing countries. International Labour Review, 152(3-4), 381 - 410. DOI: 10.1111/j.1564-913X.2013.00197.x

Rubery, J. (2003). Pay equity, minimum wages and equality at work. ILO Working Paper 19 , Geneva

Stanković, S. (2016). The Transformation of The Serbian Labour Market from a Gender Perspective. Economic Themes, 54(4), 587-604. DOI: 10.1515/ethemes-2016-0030

Statistical Office of the Republic of Serbia from http://www.stat.gov.rs/sr-Latn/oblasti/ trziste-rada/zarade

Statistical Office of the Republic of Serbia from http://www.stat.gov.rs/sr-Latn/oblasti/ trziste-rada/registrovana-zaposlenost

Statistical Office of the Republic of Serbia from https://www.stat.gov.rs/sr-Latn/oblasti/ trziste-rada/anketa-o-radnoj-snazi

Statistical Office of the Republic of Serbia from https://publikacije.stat.gov.rs/G2019/Pdf/ G201910107.pdf

The Poverty Site / The UK site for statistics on poverty and social exclusion (2010). Low pay by industry. From: http://www.poverty.org.uk/low-pay-by-industry/

Tvrdon, M., \& Skokan, K. (2011). Regional disparities and the ways of their measurement: the case of the Visegrad Four countries. Technological and economic development of economy, 17, (3), 501-518. DOI: 10.3846/20294913.2011.603485

Xing, C. \& Xu, J. (2016). Regional variation of the minimum wages in China, IZA Journal of Labor \& Development, 5 (8). DOI: 10.1186/s40175-016-0054-X

Vukmirović, J. (2013). Regionalni razvoj kao preduslov za izlazakiz krize. Makroekonomske analize i trendovi, 39-43 